\title{
An Examination of the Relationships Between Parenting Behaviors and Adolescents Well-being: A Cross-cultural Comparision
}

\author{
Ebeveyn Davranışlar ile Ergenlerin İyi Oluşu Arasındaki İlişkilerin İncelenmesi: Bir Kültürlerarası Karşılaştırma
}

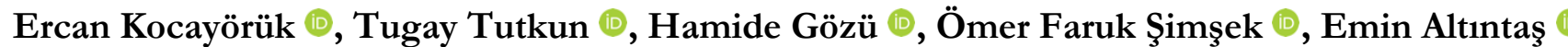

\begin{tabular}{l}
\hline Authors Information \\
Ercan Kocayörük \\
Professor, Çanakkale Onsekiz Mart \\
University, Çanakkale, Turkey \\
kocayoruk@,comu.edu.tr \\
Tugay Tutkun \\
Associate Professor, Çanakkale \\
Onsekiz Mart University, Çanakkale, \\
Turkey tugay@,comu.edu.tr \\
Hamide Gözü \\
Assistant Professor, Çanakkale \\
Onsekiz Mart University, Çanakkale, \\
Turkey hamidegozu@,comu.edu.tr \\
Ömer Faruk Şimşek \\
Professor, İstanbul Rumeli University, \\
İtanbul, Turkey simsekof@gmail.com \\
Emin Altıntaş
\end{tabular}

Associate Professor, Université de Lille, Lille, France emin.altintas@univlille.fr

\begin{tabular}{l}
\hline Article Information \\
\hline Keywords \\
Parental Control \\
Autonomy-Support \\
Responsiveness \\
Well-Being \\
Adolescents \\
Anahtar Kelimeler \\
Ebeveyn Kontrolü \\
Otonomi Desteği \\
Duyarll1k \\
Iyi-Oluş \\
Ergenler \\
Article History \\
Received: $27 / 08 / 2020$ \\
Revision: $16 / 09 / 2021$ \\
Accepted: $28 / 10 / 2021$
\end{tabular}

\section{ÖZET}

Bu çalışmanın amacı, Fransa ve Türkiye'deki ergenlerin iyi oluşları ile ebeveynlik davranışları (anne ve baba) arasındaki ilişkiyi incelemektir. Ortalama yaşları $20.85 \pm 3,18$ yıl olan 283 Fransız ve 324 Türk olmak üzere toplam 607 üniversite öğrencisi çalıșmaya dahil edilmiștir. Araștırmada algılanan ebeveynlik davranışları (davranıssal kontrol, psikolojik kontrol, özerklik ve duyarllık) ve iyilik halinin iki göstergesi, olumlu ve olumsuz duygulanım ile psikolojik iyi oluş değișkenlerinin ilișkisi incelenmiștir. Korelasyon ve regresyon analizleri ebeveynlik davranıșları ile iyilik hali göstergeleri arasında önemli bir ilişkinin olduğunu ortaya çıkarmıştır. İlk olarak hem anne hem de babaya ait psikolojik kontrol tutumunun iki ülkede olumsuz duygulanımla ilişkisinin yüksek olduğu fakat bu ilişkinin Türk örnekleminde daha yüksek olduğu bulunmuştur. Ayrıca psikolojik kontrol, sadece Türk örnekleminde, ergenlerin psikolojik gelişmesi ile negatif bir ilişkisi olduğu ortaya konulmuștur. İkincisi, Türk grubunda Fransız grubuna göre, anne ve babanın davranışsal kontrolü ile olumsuz duygulanımla arasındaki ilişkinin derecesinin daha düşük; psikolojik iyi oluşla ilişkisinin ise daha yüksek olduğu belirlenmiştir. Ek olarak, Türk anne/baba duyarlllığı ve özerklik desteğinin, düşük olumsuz duygulanımla ve baba özerklik desteğinin ise yüksek olumlu duygulanımla ilişkili olduğu bulunmuştur.

Cite this article as: Kocayörük E., Tutkun, T., Gözü, H., Şimşek, Ö.F., \& Altıntaş, E. (2021 An examination of the relationships between parenting behaviors and adolescents well-being: A cross-cultural comparision. Turkish Psychological Counseling and Guidance Journal, 11(63), 487-504. 


\section{INTRODUCTION}

Parenting behaviors have been widely paid attention to across various cultures. Many research findings in individualistic cultures have shown that high psychological control has been associated with negative consequences such as high depressive symptoms (Barber, 1996) and poor self-esteem (Bean et al., 2003) whereas behavioral control, autonomy support, and responsiveness have been associated with positive outcomes such as fewer problem behaviors and higher life satisfaction (Chao \& Aque, 2009; Kins et al., 2009). Studies from collectivist cultures, however, have shown inconsistent findings regarding the parental behaviors and well-being (Chao \& Aque, 2009; Wang et al., 2016); some parental behaviors were found to be associated with negative outcomes as they were in individualistic cultures whereas the others were not related to developmental outcomes. Those studies suggest that whether the associations between such parenting behaviors and developmental outcomes are universal (or cultural-specific) is not clear yet. Moreover, it is believed that examining children's positive functionings (psychological flourishing) in addition to their emotional dimensions of subjective well-being (positive and negative affect) would offer a better understanding of well-being since these constructs are accepted as indicators of well-being (Gök \& Kocayörük, 2019; Martín-Carbonell et al., 2021). For that reason, the current study aimed to examine the link between parenting behaviors and adolescents' well-being in two different countries; one country shows individualistic orientations, France and the other country shows both individualistic and collectivist orientations, Turkey.

\section{Parenting and Culture}

Parenting behaviors may differ across various countries because such behaviors reflect relationships between family and other community members and values within the cultural context. Culture does not only affect parenting behaviors it also shapes the association between parenting behaviors and developmental outcomes (Rudy \& Grusec, 2006). Parents in individualistic cultures emphasize the value of autonomy of each family member and positivism no matter what happens and encourage children to make their personal decisions and achieve their full potential (Tamis-LeMonda, et al., 2008). On the other hand, parents in collectivist cultures highlight the importance of loyalty to family and larger the group, respect, and obedience to elders, and scarifying the individual interest for the good of the group (Markus \& Kitayama, 1991; Tamis-LeMonda, et al., 2008).

Crockett and colleagues (2010, p. 31) suggest that parenting behaviors are likely to have different meanings in different cultures as they are "embedded in culturally-based meaning systems" phenomena. One of the factors influencing the differential associations is the perceived normativeness of parental control in the culture that parenting behaviors (e.g., parental control) are perceived as acceptable in collectivist culture; thus, such behaviors do not reflect parental rejection (Kağıtçıbaş1, 1996). Second, what parenting styles mean may differ from one culture to another (Chao, 1994; Chao \& Aque, 2009; Rudy \& Halgunseth, 2005). For example, Chao reported that the high levels of strict control were perceived simultaneously as loving in Chinese samples.

Third, the feelings associated with perceived parenting behaviors may vary across cultures. For example, East Asian adolescents were less likely to feel angry towards behavioral and psychological control than European counterparts (Chao \& Aque, 2009) and to evaluate social comparison, shame, and love withdrawal less negatively than European-Canadians counterparts (Helwig et al., 2014). Similarly, Güngör 
(2008) revealed that Turkish adolescents living in Belgium reported greater maternal control together with higher emotional satisfaction in relationships with their mothers than did Belgian adolescents.

One of the parenting behaviors nurturing children's needs is parental autonomy support. Parental autonomy support refers to parental encouragement of the adolescent towards independent expression and decision-making. Prior research in individualistic culture has revealed that parental autonomy support was associated with positive outcomes such as a high level of well-being (Kins et al., 2009; Soenens et al., 2007; Wang, et al., 2007) and fewer depressive symptoms (Van der Giessen, et al., 2014). Studies conducted in collectivist cultures showed a similar pattern; high parental autonomy support was associated with a high level of well-being among Chinese (Wang et al., 2007) and Chinese Malaysian adolescents (Downie et al., 2007), high level of self-esteem among Latino adolescents (Bean \& Northrup, 2009) and low level of depressive symptoms among Chinese (To et al., 2017). Lan and colleagues (2019) found a similar pattern for Tibetian and Han ethnic groups; perceived parental autonomy support positively contributed to emerging adults' flourishing.

Like autonomy-support, parental responsiveness (parental warmth and emotional support) has been found associated with positive outcomes by numerous studies. Research from individualistic cultures has revealed that such parenting behavior was related to a high level of flourishing (Chen et al., 2019), high academic achievement (Fletcher et al., 2008; Kocayörük, 2007) low externalized problems (Fletcher et al., 2008), and high self-esteem (Suchman et al., 2007). Similarly, parental warmth was associated with high self-esteem in collectivist cultures (Rudy \& Grusec, 2006).

Psychological control, which is the parental attempts to control an adolescent's psychological world (e.g., feelings and thoughts) through psychological methods such as withdrawing love and inducing guilt (Barber, 2002). Studies from various cultures point to mixed results regarding the association between parental psychological control and well-being. Research conducted in individualistic cultures consistently showed that psychological control hurt adolescent functioning such as high depressive symptoms (Barber, 1996), poor self-esteem (Bean et al., 2003), and high levels of negative emotions (Zarra-Nezhad et al., 2015). For collectivist cultures, there is an inconsistent pattern. Some researchers have revealed a negative correlation between parental psychological control and self-esteem (Bean \& Northrup, 2009; Ngai \& Cheung, 2009) as well as emotional well-being (Wang et al., 2007) among Chinese adolescents as it is in individualistic cultures. On the other hand, Bush and colleagues (2002) found that psychological control was not correlated with well-being among Chinese adolescents residing in Mainland China.

The positive associations between parental behavioral control and developmental outcome are consistent across the cultures. High parental behavioral control was associated with externalized constructs such as fewer problem behaviors (Chao \& Aque, 2009), antisocial behaviors (Kocayörük \& Sümer, 2009; Laird et al., 2010), and low levels of negative emotions (Zarra-Nezhad et al., 2015) but not associated with internalized constructs (see Barber, 1996) in individualistic cultures. A similar pattern was evident for Turkish adolescents; when mothers were perceived behaviorally controlling, male adolescents tended to have fewer problems (Kindap et al., 2008). Yet other research from collectivist cultures has showed a significant association between behavioral control and adolescents' emotional functioning. Parental monitoring, as well as functional and order-keeping parental control, was positively associated with selfesteem among Chinese adolescents (Lau \& Cheung, 1987). 


\section{The Current Study}

In the current study, we examined the differences in the associations between parenting behaviors and developmental outcomes in France and Turkey which two countries showed different cultural characteristics. France has been identified as one of the individualist countries with a score of 71 on individualism whereas Turkish culture has been found to have both individualistic with a score of 37 (Hofstede, 2001) and collectivist orientations (Ayçiçeği-Dinn \& Caldwell-Harris, 2011; Oyserman et al., 2002). In Turkish culture, parents support their children to be economically autonomous by encouraging them to have better education and specialize at work (Kağıtçıbaşı, 1996). Moreover, Turkish parents display control over their children to maintain closeness in the family (Sunar, 2002).

Given the fact that there are cultural variations in some of the associations of parenting behaviors to offspring's developmental outcomes between individualistic and collectivist cultures, there might be some differences in such associations across France and Turkey. The current study aimed to examine whether (1) parenting behaviors predicted adolescents' (a) Positive Affect, (b) Negative Affect, (c) Psychological Flourishing, and (2) there was a difference in the associations between parenting behaviors and adolescents' developmental outcomes across the countries.

Our research questions are listed below.

1. Do parenting behaviors (maternal/paternal responsiveness, maternal/paternal behavioral control, maternal/paternal psychological control, and maternal/paternal autonomy support) predict adolescents' Positive Affect?

2. Do parenting behaviors (maternal/paternal responsiveness, maternal/paternal behavioral control, maternal/paternal psychological control, and maternal/paternal autonomy support) predict adolescents' Negative Affect?

3. Do parenting behaviors (maternal/paternal responsiveness, maternal/paternal behavioral control, maternal/paternal psychological control, and maternal/paternal autonomy support) predict adolescents' Psychological Flourishing?

4. Is there any difference in the associations between parenting behaviors (maternal/paternal responsiveness, maternal/paternal behavioral control, maternal/paternal psychological control, and maternal/paternal autonomy support) and adolescents' Positive Affect across the countries?

5. Is there any difference in the associations between parenting behaviors (maternal/paternal responsiveness, maternal/paternal behavioral control, maternal/paternal psychological control, and maternal/paternal autonomy support) and adolescents' Negative Affect across the countries?

6. Is there any difference in the associations between parenting behaviors (maternal/paternal responsiveness, maternal/paternal behavioral control, maternal/paternal psychological control, and maternal/paternal autonomy support) and adolescents' Psychological Flourishing across the countries?

\section{METHOD}

\section{Participants and Procedure}

Data were collected from two countries: France and Turkey. A total of 607 undergraduate university students was recruited with a mean age of $20.85 \pm 3.18$ years: 283 French and 324 Turkish. The French sample was composed of 283 undergraduate native French speaker students (226 female and 57 male) 
regularly studying in the Psychology Department of Université de Lille 3 (France) (Mage $=21.14$ years, $\mathrm{SD}=3.95$, age range $=16-25$ years). One French student was only 16 years old. Turkish sample was composed of 324 undergraduate native Turkish speaker students (218 female and 106 male) regularly studying in Department of Psychological Counseling, Çanakkale Onsekiz Mart University (Turkey) (Mage $=20.96$ years, $\mathrm{SD}=3.15$, age-range $=17-25$ years). Both universities were medium-sized public universities located in medium-sized cities.

After getting permission from the university ethics committees, the researchers administrated instruments in a single class session. The participants were provided information about the purpose of the study and the procedure to be followed. Moreover, the researchers explained that participants' confidentiality would be kept and there was no obligation to participate in the study. The participants were asked to complete the instruments anonymously before returning them to the project assistants. Completion time ranged between 20 and 30 minutes. No financial compensation was provided. All participants have been debriefed and thanked for their participation.

\section{Instruments}

The data were administrated by the means of the self-report questionnaires in the sample of university students. It was designed to assess participants' descriptive data (age, gender, educational level), perceived parenting behaviors, and well-being using two indicators: (1) Positive and Negative Affect, (2) Psychological Flourishing.

Perceived Parenting Behaviors. The Leuven Adolescent Perceived Parenting Scale (LAPPS; Soenens et al., 2004) was translated into French by Delhaye et al. (2012) and Turkish by Sevim (2014). The LAPPS evaluates the perceived parental behaviors and is consisted of 28-items with four sub-dimensions: Behavioral control (7-items, e.g., "My mother/father is very strict with me"), Psychological Control (7items, e.g., "My mother/father will avoid looking at me when I have disappointed her/him"), Autonomy (7-items, e.g., "My mother/father helps me to choose my own direction"), and Responsiveness (7-items, e.g., "My mother/father makes me feel better after talking over my worries with her/him"). Students were asked to respond to each statement for their mothers and fathers separately based on a five-point Likert scale, ranging from "Completely disagree" to "Completely agree". Responses were averaged using continuous scores on each parenting behavior. These scores could range from 1 to 5 . High scores for each sub-scale indicate a high level (range from 1 to 5 for each sub-scale). In the current study, the internal consistency of the scale was adequate (French sample, alpha for mother $=0.67$, alpha for father $=0.73$; Turkish sample, alpha for mother $=.71$, alpha for father $=.75)$.

Well-Being. The Positive and Negative Affect Schedule (PANAS; Watson et al., 1988) was translated into French by Bouffard and Lapierre (1997) and Turkish by Gençöz (2000). The PANAS is a 20 -item self-report scale that measures the positive affect (10 items, e.g., "happy") and negative affect (10 items, e.g., "nervous"). Students were asked to indicate their agreement with statements about themselves on a 5-point Likert scale ranging from 1 (very slightly or not at all), to 5 (extremely). High scores for each subscale indicate a high level of positive or negative affect (range from 10 to 50 for each sub-scale). In the current study, the internal consistency of the PANAS was satisfactory (French sample: alpha $=.84$; Turkish sample: alpha $=.87$ ).

The Psychological Flourishing scale (PFS; Diener et al., 2010) was translated into French by Villieux et al. (2016) and Turkish by Akın and Fidan (2012). PFS is an 8-item self-report and unidimensional scale 
that measures used individuals" psychological flourishing (e.g. "People respect me"). Students were asked to indicate their agreement with statements about themselves on a 7-point Likert scale ranging from 1 (strongly disagree), to 7 (strongly agree). The scores of the items were averaged into an overall psychological flourishing score. A higher score indicates a high level of psychological flourishing (range from 8 to 56). In the current study, the internal consistency of the PFS was satisfactory (alpha $=.83$ for the French sample; alpha $=.85$ for the Turkish sample).

\section{Statistical Analyses}

Statistical analyses were conducted with Statistica 7 software in four steps. First, means, standard deviations, and correlations between all variables of the study were computed on the total sample comprising Turkish and French university students. Second, the coefficients of correlations between mothers and fathers for each behavior of the Leuven parenting scale (e.g., behavioral control, psychological control, responsiveness, and autonomy) were computed in the Turkish and French samples to examine if these correlations were similar in two groups. Third, in the total sample, the predictive power of parenting behaviors of the mother and father on late adolescents' affect, and psychological flourishing were evaluated. In the final step, the same predictive relationships were also tested with country variables to test if the parenting predictive power differed between these two countries.

\section{RESULTS}

\section{Preliminary Analyses}

Means, standard deviations, and correlations for all variables of the study were presented in Table 1 . The positive affect was systematically related to the mother and father parenting behaviors, except psychological control.

\begin{tabular}{|c|c|c|c|c|c|c|c|c|c|c|c|c|}
\hline & Mean & SD & 1. & 2. & 3. & 4. & 5. & 6. & 7. & 8. & 9. & 10. \\
\hline 1. Maternal BC & 2.42 & 0.85 & & & & & & & & & & \\
\hline 2. Maternal PC & 2.74 & 1.09 & $.16^{* *}$ & & & & & & & & & \\
\hline 3. Maternal R & 4.16 & 0.84 & $-.15^{* *}$ & $-.45^{* *}$ & & & & & & & & \\
\hline 4. Maternal A & 3.84 & 0.66 & $-.36 * *$ & $-.19 * *$ & $.52 * *$ & & & & & & & \\
\hline 5. Paternal BC & 2.49 & 0.89 & $.44^{* *}$ & .05 & -.03 & $-.15^{* *}$ & & & & & & \\
\hline 6. Paternal PC & 2.69 & 1.07 & -.06 & $.56^{* *}$ & $-.25^{* *}$ & $-.08 *$ & $.19 * *$ & & & & & \\
\hline 7. Paternal R & 3.51 & 1.07 & 0.02 & $-.22 * *$ & $.29 * *$ & $.17 * *$ & $-.19 * *$ & $-.34 * *$ & & & & \\
\hline 8. Paternal A & 3.61 & 0.75 & -.06 & $-.14 * *$ & $.3 * *$ & $.38^{* *}$ & $-.37 * *$ & $-.2 * *$ & $.46^{* *}$ & & & \\
\hline 9. PANAS + & 3.25 & 1.02 & $-.13 * *$ & -.01 & $.11 * *$ & $.15^{* *}$ & $-.12^{* *}$ & .01 & $.12^{* *}$ & $.14^{* *}$ & & \\
\hline 10. PANAS - & 2.14 & 1.00 & -.08 & $.41 * *$ & $-.27 * *$ & $-.19 * *$ & -.06 & $.40 * *$ & $-.16^{* *}$ & $-.16^{* *}$ & $.18^{* *}$ & \\
\hline 11. PF & 5.88 & 0.77 & .06 & $-.18 * *$ & $.25^{* *}$ & $.20 * *$ & .07 & $-.14 * *$ & $.15^{* *}$ & $.16^{* *}$ & .02 & $-.27 * *$ \\
\hline
\end{tabular}

As seen in Table 2, the correlations for each parenting behavior were computed for mother and father in the total sample and then separately in Turkish and French samples. The difference between the two coefficients of correlation was assessed with Fisher' $r$ to $z$ transformations whether the mother' and father's parenting behaviors varied between Turkish and French samples (see Table 2). The findings revealed that there were significant differences in the correlations between parenting behaviors among Turkish and French samples. The coefficients of correlations between Turkish and French were similar for responsiveness $(z=1.12, p>.05)$ and autonomy $(z=-0.13, p>.05)$, but significant differences appeared for behavioral control $(\mathrm{z}=2.25, \mathrm{p}<.05)$ and psychological control $(\mathrm{z}=4.86, \mathrm{p}<.001)$. These results 
indicated cross-cultural differences in relationships of parenting behaviors and adolescents' outcomes. It seems necessary to explore more deeply those relationships.

Table 2. Comparisons of the Coefficients of Correlation between French and Turkish samples

\begin{tabular}{|c|c|c|c|c|}
\hline Parenting Behaviors & Turkish & France & Difference $(\mathrm{z})$ & $p$ \\
\hline $\begin{array}{l}\text { Behavioral Control } \\
\text { Mother-Father }\end{array}$ & $.51 * *$ & $.36^{* *}$ & 2.25 & .024 \\
\hline $\begin{array}{l}\text { Psychological Control } \\
\text { Mother-Father }\end{array}$ & $.69^{* *}$ & $.42 * *$ & 4.86 & .000 \\
\hline $\begin{array}{l}\text { Responsiveness } \\
\text { Mother-Father }\end{array}$ & $.33^{* *}$ & $.25^{* *}$ & 1.12 & .263 \\
\hline $\begin{array}{l}\text { Autonomy } \\
\text { Mother-Father }\end{array}$ & $.38^{* *}$ & $.39 * *$ & -0.13 & .897 \\
\hline
\end{tabular}

$\mathrm{N}$ Turkish $=324 ; \mathrm{N}$ French $=283,{ }^{* *} \mathrm{p}<.01$ (2 tailed).

The Relationships between Maternal and Paternal Parenting Behaviors and Adolescents' Outcomes

To examine the relationships between parenting behaviors and adolescent outcomes among two samples, twelve regression analyses were run. The analyses revealed that maternal and paternal parenting behaviors have predicted significantly positive and negative affect and psychological flourishing of adolescents (see Table 3).

Table 3. Summary of Regression Analyses between Parentings Behaviors and Dependent Variables of Study (PANAS Positive, PANAS Negative, and Psychological Flourishing) in Total Sample

\begin{tabular}{lccc}
\hline & Panas_positive & Panas_negative & Psychological Flourish \\
\hline Mother & $\beta$ & $\beta$ & $\beta$ \\
Beh.Control & $-.13^{* * *}$ & -.08 & .07 \\
Beh.ControlXCountry & -.02 & $.14^{* * *}$ & $-.09^{*}$ \\
Psyc.Control & -.01 & $.41^{* * *}$ & $-.18^{* * *}$ \\
Psyc.ControlXCountry & -.01 & $-.23^{* * *}$ & $.15^{* * *}$ \\
Responsiveness & $.11^{* *}$ & $-.27^{* * *}$ & $.25^{* * *}$ \\
ResponsivenessXCountry & -.03 & $.22^{* * *}$ & -.05 \\
Autonomy & $.15^{* * *}$ & $-.19^{* * *}$ & $.20^{* * *}$ \\
AutonomyXCountry & -.02 & $.09^{*}$ & -.01 \\
Father & & & .07 \\
Beh.Control & $-.12^{* *}$ & -.06 & -.06 \\
Beh.ControlXCountry & .08 & $.12^{* *}$ & $-.14^{* * *}$ \\
Psyc.Control & .01 & $.41^{* * *}$ & $.15^{* * *}$ \\
Psyc.ControlXCountry & .00 & $-.23^{* * *}$ & $.15^{* * *}$ \\
Responsiveness & $.12^{* *}$ & $-.16^{* * *}$ & -.05 \\
ResponsivenessXCountry & -.01 & .05 & $.16^{* * *}$ \\
Autonomy & $.14^{* * *}$ & $-.16^{* * *}$ & .02 \\
AutonomyXCountry & $-.10^{*}$ & $.11^{* * *}$ & \\
\hline
\end{tabular}

$\mathrm{N}=607,{ }^{*} \mathrm{p}<.05 ; * * \mathrm{p}<.01 ; * * * \mathrm{p}<.001$.

As seen in Table 3, considering the maternal parenting behaviors, behavioral control negatively predicted Positive Affect $(\beta=-.13, \mathrm{p}<.001)$ whereas both responsiveness and autonomy positively predicted Positive Affect $(\beta=.11, \mathrm{p}<.01$ for responsiveness; $\beta=.15, \mathrm{p}<.001$ for autonomy). There was a similar pattern of paternal parenting behaviors. Paternal behavioral control negatively predicted Positive Affect $(\beta=-.12, p<.002)$ whereas both responsiveness and autonomy positively predicted Positive Affect $(\beta=.12$, $\mathrm{p}<.01$ for responsiveness; $\beta=.14, \mathrm{p}<.001$ for autonomy). 
Moreover, Table 3 shows that maternal psychological control positively predicted Negative Affect $(\beta=$ $.41, \mathrm{p}<.001)$ whereas both responsiveness and autonomy positively negatively predicted Negative Affect $(\beta=-.27, p<.001$ for responsiveness; $\beta=-.19, \mathrm{p}<.001$ for autonomy). Similarly, paternal psychological control positively predicted Negative Affect $(\beta=41, \mathrm{p}<.001)$ whereas both responsiveness and autonomy negatively predicted Negative Affect $(\beta=-.16, p<.001$ for responsiveness; $\beta=-.16, p<.001$ for autonomy).

In addition to findings of parenting and PANAS, Table 3 also shows that maternal psychological control negatively predicted Psychological Flourishing $(\beta=-.18, \mathrm{p}<.001)$ while both responsiveness and autonomy positively predicted Psychological Flourishing $(\beta=.25, \mathrm{p}<.001$ for responsiveness; $\beta=.20$, $\mathrm{p}<.001$ for autonomy). As seen in Table 3, for paternal parenting behaviors, psychological control negatively predicted Psychological Flourishing $(\beta=-.14, \mathrm{p}<.001)$ while both responsiveness and autonomy positively Psychological Flourishing $(\beta=.15, \mathrm{p}<.001$ responsiveness; $\beta=.16, \mathrm{p}<.001$ for autonomy).

In summary, psychological control was predictive of high negative affect and low psychological flourishing whereas both parental responsiveness and autonomy were predictive of high positive affect and high psychological flourishing. Interestingly, parental behavioral control was predictive of low positive affect.

\section{Country Differences in the Relationships of Parenting Behaviors to Adolescents Outcomes}

The results of regression analysis indicated that there were cultural differences in the relationships between some parenting behaviors and adolescent outcomes (see Table 3). Therefore, it seems necessary to explore more deeply the parenting behaviors between the two samples. As seen in Table 4, post-hoc analyses revealed significant differences between parenting behaviors and well-being comparing the two samples.

Table 4. Summary of Regression Analyses between Parenting Behaviors and Dependent Variables of Study (PANAS positive, PANAS negative, and Psychological Flourishing) in French and Turkish samples

\begin{tabular}{|c|c|c|c|c|c|c|}
\hline & \multicolumn{3}{|c|}{ France } & \multicolumn{3}{|c|}{ Turkey } \\
\hline & $\begin{array}{c}\text { Positive } \\
\text { Affect } \\
\beta\end{array}$ & $\begin{array}{c}\text { Negative } \\
\text { Affect } \\
\beta\end{array}$ & $\begin{array}{c}\text { Psycho } \\
\text { Flourishing } \\
\beta\end{array}$ & $\begin{array}{c}\text { Positive } \\
\text { Affect } \\
\beta\end{array}$ & $\begin{array}{c}\text { Negative } \\
\text { Affect } \\
\beta\end{array}$ & $\begin{array}{c}\text { Psycho } \\
\text { Flourishing } \\
\beta\end{array}$ \\
\hline Mother & & & & & & \\
\hline Behavioral control & & .06 & -.03 & & $-.20 * * *$ & $.15^{* *}$ \\
\hline Psychological control & & $.18^{* * *}$ & -.03 & & $.60 * * *$ & $-.31 * * *$ \\
\hline Responsiveness & & -.05 & & & $-.47 * * *$ & \\
\hline Autonomy & & -.11 & & & $-.25^{* * *}$ & \\
\hline Father & & & & & & \\
\hline Behavioral control & & .07 & & & $-.16^{* *}$ & \\
\hline $\begin{array}{l}\text { Psychological control } \\
\text { Responsiveness }\end{array}$ & & $.18^{* * *}$ & .02 & & $.60 * * *$ & $-.27 * * *$ \\
\hline Autonomy & .05 & -.05 & & $.22^{* * *}$ & $-.25^{* * *}$ & \\
\hline
\end{tabular}

Note: The significant values in Table 3 are reported in Table 4.

$\mathrm{N}=607$ ( $\mathrm{N}$ Turkish= 324; $\mathrm{N}$ French $=283$ ), ${ }^{*} \mathrm{p}<.05 ;{ }^{* *} \mathrm{p}<.01 ; * * * \mathrm{p}<.001$.

The interaction term of the regression analysis for Negative Affect, reported in Table 3, showed that there was a difference due to country in the relationships between Negative and maternal behavioral control $(\beta=.14, \mathrm{p}<.001)$. Recall that maternal behavioral control was not associated with Negative Affect. However, posthoc analyses revealed that maternal behavioral control negatively predicted Negative 
Affect in the Turkish sample $(\beta=-.20, \mathrm{p}<.001)$ whereas there was no significant association between maternal behavioral control and Negative Affect in the French sample (see Table 4). Moreover, the relationships between Negative and other maternal parenting behaviors also varied across the countries: psychological control $(\beta=-.23, p<.001)$, responsiveness $(\beta=-.22, p<.001)$, and autonomy support $(\beta=.09$, $\mathrm{p}<.05)$. Post-hoc analyses revealed that maternal responsiveness $(\beta=-.47, \mathrm{p}<.001)$ and autonomy support $(\beta=-.25, \mathrm{p}<.001)$ significantly predicted Negative Affect in the Turkish sample whereas such maternal behaviors were not related to Negative Affect in the French sample. As seen in Table 4, maternal psychological control was positively associated with Negative Affect in both countries although the association between maternal psychological control and Negative Affect in the Turkish sample $(\beta=.60$, $\mathrm{p}<.001)$ was larger than the maternal psychological control in the French sample $(\beta=.18, \mathrm{p}<.001)$.

Most of the findings regarding maternal behaviors and adolescent well-being in the current samples were consistent with paternal behaviors and adolescents' well-being findings. There was a difference due to country in the relationships between Negative Affect and paternal behavioral control $(\beta=.12, \mathrm{p}<.001)$. Moreover, the relationships between Negative Affect and other two paternal parenting behaviors also differed across the countries: psychological control $(\beta=-23, \mathrm{p}<.001)$, and autonomy support $(\beta=.11$, $\mathrm{p}<.001)$. Post-hoc analyses revealed that paternal autonomy support $(\beta=-.25, \mathrm{p}<.001)$ significantly predicted Negative Affect in the Turkish sample, whereas such maternal behaviors were not related to Negative Affect in the French sample (see Table 4). As seen in Table 4, paternal psychological control was positively associated with PANAS Negative in both countries; although the correlation coefficient of paternal psychological control in the Turkish sample $(\beta=.60, p<.001)$ was larger than the correlation coefficient of paternal psychological control in the French sample $(\beta=.18, \mathrm{p}<.001)$.

Similarly, the interaction term of the regression analysis for Psychological Flourishing reported in Table 3 , showed that there was a difference due to country in the relationships between Psychological Flourishing and maternal behavioral control $(\beta=-.09, \mathrm{p}<.05)$, on the other hand, paternal behavioral control was not associated with Psychological Flourishing. However, posthoc analyses revealed that maternal behavioral control negatively predicted Psychological Flourishing in the Turkish sample $(\beta=.15$, $\mathrm{p}<.001)$ whereas there was no significant association between maternal behavioral control and Psychological Flourishing in the French sample (see Table 4). Moreover, the relationship between Psychological Flourishing and maternal psychological control also differed across the countries $(\beta=.15$, $\mathrm{p}<.001)$. Post-hoc analyses revealed that maternal psychological control significantly predicted Psychological Flourishing in the Turkish sample $(\beta=-.31, \mathrm{p}<.001)$ whereas such maternal behaviors were not related to Negative Affect in the French sample (see Table 4). In addition to this, for paternal parenting, there was a country difference in the relationships between psychological parenting and Psychological Flourishing $(\beta=.15, \mathrm{p}<.001)$. Post-hoc analyses revealed that paternal psychological control significantly predicted Psychological Flourishing in the Turkish sample $(\beta=-.27, p<.001)$ whereas such maternal behaviors were not related to Negative Affect in the French sample (see Table 4).

In summary, both maternal and paternal psychological parenting was associated with high negative affect in the two countries, although the correlation coefficients were different. First, that both maternal and paternal psychological controlling in the Turkish and French groups was associated with high negativeaffect. And this association is higher in the Turkish group than the French group. Moreover, psychological control was associated with a decrease in psychological flourishing only in the Turkish group. In addition, maternal and paternal behavioral control was associated with lower negative-affect 
while the Turkish maternal behavioral control was associated with and higher psychological-flourishing in the Turkish group than the French group. Furthermore, both maternal and paternal responsiveness, as well as autonomy support, were associated with lower negative affect and paternal autonomy support was associated with high positive affect in the Turkish sample only.

\section{DISCUSSION}

The current study aimed to examine the associations between parental behaviors and adolescents' wellbeing in two countries, France and Turkey. The findings showed that parenting behaviors were associated with developmental outcomes; furthermore, they showed that the associations between parenting and developmental outcomes were moderated by country. Mostly both maternal and paternal parenting behaviors were significantly associated with adolescents' well-being in the Turkish sample.

\section{Relationships between Parenting Behaviors and Adolescents' Outcomes}

We examined whether parental behaviors were related to adolescents' developmental outcomes, including Positive Affect, Negative Affect, and Psychological Flourishing because previous research had suggested that parental behavioral and psychological control, and responsiveness and autonomy support can have an impact on psychological well-being (e.g. Bean et al., 2003; Ngai \& Cheung, 2009; Wang et al., 2007). The current study revealed mixed results regarding the association of behavioral control with adolescent outcomes. Low behavioral control was associated with high Negative Affect and low Psychological Flourishing in the Turkish sample. This finding is consistent with previous studies suggesting parental behaviors related to internalized constructs such as self-esteem in non-Western cultures (Bush et al., 2002; Chao \& Aque, 2009; Lau \& Cheung, 1987). On the other hand, interestingly, both maternal and paternal behavioral control, parenting was negatively associated with the positive affect of adolescents in both countries; recall that behavioral control is often related to externalized constructs such as delinquency and substance abuse but not internalized construct (e.g. self-esteem) in Western cultures (see Barber, 1996; Bean et al., 2003). Why behavioral control is associated with low positive affect in France and Turkey needs further explanation. Wang et al. (2007) suggest that the distinction between psychological and behavioral control might not be always clear. Parents might apply guilt induction to control offspring's behaviors; thus, behavioral control might have a role in the offspring's emotional development as well.

The findings of the current study suggest that psychological control is the highest predictive power of parenting in both cultures. It emerges as a universal phenomenon that both the mother and the father's psychological control is related to negative emotions. This finding is consistent with previous research showing the link between psychological control and the inability to develop a sense of competence (Barber, 1996), lack of confidence, or internalizing problems in children (Grolnick \& Rfatery-Helmer, 2013), and high depressive symptoms (Barber, 1996). During adolescence, offspring puts more weight on how they are treated or controlled. Parents may not always meet the needs of their offspring (support and responsiveness); they might try to shape adolescents' psychological and emotional development. During this period, perceived parental control is likely to have an important place in adolescence' wellbeing (Sönmez, 2011).

Consistent with previous research from various cultures (Bean \& Northrup, 2009; Kins et al., 2009; Soenens et al., 2007; Van der Giesen et al., 2014, Zarra-Nezhad et al., 2015), it was revealed that both parental autonomy support and responsiveness were associated with high positive affect and 
psychological flourishing and lower negative affect in the current. The finding of the study lends support to the notion that the need for autonomous behavior is universal (Chirkov et al., 2003). The need for autonomous behavior is dominated by late adolescence and inevitably influenced by relationships with parents. During this period, many late adolescents are likely to leave their homes to study for a bachelor's degree. Although most Turkish late adolescents are not economically autonomous, they live in separate residential settings and are more likely to make autonomous decisions. The support for late adolescents from their parents and the restructuring of their relations with the positive contribution or hindrance is foregrounded. Thus, parental autonomy support and responsiveness in this period, contribute to late adolescents' well-being.

\section{Cultural Moderation}

Another remarkable finding emerging from our analyses is the moderating role of the country in the associations between parental behaviors and developmental outcomes. The majority of the associations are significant in the Turkish sample only. However, this finding should be evaluated carefully. Given that the directions of associations between parenting behaviors and developmental outcomes in the current study are consistent with findings of other studies from various cultures, our findings suggest that the link between parenting and the developmental outcome is universal but the salience of a given fundamental developmental process may vary across cultures. Why these associations are significant in the Turkish sample only might be related to the parent-child relationships at certain ages. One possible explanation is that the participants were college-aged adolescents in the current study, and it may be that Turkish parents have more interaction with their college-aged adolescents specifically than their French counterparts.

The analyses of the study also showed that the patterns of associations of parenting to developmental outcomes are different for Turkish mothers and fathers. For example, paternal autonomy support, but not maternal autonomy support, is associated with positive emotions, whereas maternal responsiveness, but not paternal responsiveness, is associated with low negative affect. Such differences might derive from differential parenting behaviors between Turkish mothers and fathers. Fathers are more likely than mothers to support their children to autonomously make decisions about their future while mothers are more likely than fathers to involve childcare (Bespinar \& Aybars, 2014). For these reasons, particularly paternal autonomy support and maternal responsiveness might have strong associations with adolescents' well-being.

\section{General Implications of The Study}

An important implication of the current study's findings is that researchers should not overgeneralize conclusions from one group to another since we found that some associations between parenting behaviors and well-being depended on the country. Therefore, psychologists should be sensitive to other group differences within countries. Moreover, our study revealed differential parenting behaviors between Turkish mothers and fathers. For that reason, treating fathers and mothers as equivalent in terms of their behavior or influence might be misleading. Psychologists should focus on both paternal and maternal parenting to promote a child's wellbeing.

\section{Limitations and Future Research}

Some limitations should be highlighted in the present study. One of the limitations is that the current study included adolescents' perceptions of parenting behaviors only. Adolescents' reports might not 
reflect actual parental behaviors. Collecting information from both parents and adolescents would help to investigate the differential associations of developmental outcomes and parental behaviors. Second, there might be other factors associated with the link between parenting behaviors and adolescents' wellbeing such as gender, SES, and age (child vs. adolescent). For that reason, examining the role of such factors in the link between parenting behaviors and developmental outcomes would give much richer information about the complex influence of parenting behaviors.

Finally, the type of living area (rural vs. urban) can be also an important context for the psychological controlling of parents. For instance, Pomerantz and Wang (2009) argue that since people in the urban areas in China are more likely to expose to Western values than people in rural areas, parental psychological control might have a stronger negative influence in some areas. Thus, future studies should examine the associations of parenting behaviors to adolescent outcomes in different living areas to enlighten how globalization might play role in such associations.

In conclusion, the findings of the current study revealed that parenting behaviors were universally related to positive and negative emotions among adolescents from France and Turkey. However, for some associations between parenting behaviors and well-being depended on the country. The findings suggest that researchers should not generalize the findings from one country to another. 


\section{REFERENCES}

Akın, A., \& Fidan, M. (2012). The validity and reliability of the Turkish version of the Flourishing Scale. In 3rd International Conference on New Trends in Education and their Implications (ICONTE-2012), April (pp. 26-28).

Ayçiçegi-Dinn, A., \& Caldwell-Harris, C.L. (2011). Individualism-collectivism among Americans, Turks, and facilitating Turkish immigrants to the US. International Journal of Intercultural Relations, 35(1), 9-16. https://doi.org/10.1016/j.ijintrel.2010.11.006

Barber, B.K. (1996). Parental psychological control: Revisiting a neglected construct. Child Development, 67(6), 32963319. https://doi.org/10.2307/1131780

Bean, R.A., Bush, K.R., McKenry, P.C., \& Wilson, S.M. (2003). The impact of parental support, behavioral control, and psychological control on the academic achievement and self-esteem of African American and European American adolescents. Journal of Adolescent Research, 18(5), 523-541. https://doi.org/10.1177/0743558403255070

Bean, R.A., \& Northrup, J.C. (2009). Parental psychological control, psychological autonomy, and acceptance as predictors of self-esteem in Latino adolescents. Journal of Family Issues, 30(11), 1486-1504. https://doi.org/10.1177/0192513X09339149

Beşpınar, F.U. \& Aybars, A.İ. (2013). Erken yaşlarda çocuk refahı ve kadın istihdamı politika belgesi [Early childhood welfare and women employment policy document]. Unicef Publications Retrieved from: http://www.sck.gov.tr/oecd/Erken\%20Yas\%CC\%A7larda\%20C\%CC\%A7ocuk\%20Refah\%C4\%B1\%20 ve $\% 20 \mathrm{Kad} \% \mathrm{C} 4 \% \mathrm{~B} 1 \mathrm{n} \% 20 \% \mathrm{C} 4 \% \mathrm{~B} 0$ stihdam\%C4\%B1\%20Politika\%20Belgesi.pdf.

Bouffard, L., \& Lapierre, S. (1997). La mesure du bonheur [The Measurement of Happiness]. Revue Québécoise de Psychologie 18 (2), 271-310. https://doi.org/10.7202/1040067ar

Bush, K.R., Peterson, G.W., Cobas, J.A., \& Supple, A.J. (2002). Adolescents' perceptions of parental behaviors as predictors of adolescent self-esteem in Mainland China, Sociological Inquiry, 72(4), 503526. https://doi.org/10.1111/1475-682X.00031

Chao, R.K. (1994). Beyond parental control and authoritarian parenting style: Understanding Chinese parenting through the cultural notion of training. Child Development, 65(4), 1111-1119. https://doi.org/10.2307/1131308

Chao, R.K., \& Aque, C. (2009). Interpretations of parental control by Asian immigrant and European American youth. Journal of Family Psychology, 23(3), 342-354. https://doi: 10.1037/a0015828.

Chen, Y., Kubzansky, L. D., \& VanderWeele, T. J. (2019). Parental warmth and flourishing in mid-life. Social science \& Medicine (1982), 220, 65-72. https://doi.org/10.1016/j.socscimed.2018.10.026

Chirkov, V., Ryan, R.M., Kim, Y., \& Kaplan, U. (2003). Differentiating autonomy from individualism and independence: A Self-Determination Theory perspective on internalization of cultural orientations and wellbeing. Journal of Personality and Social Psychology, 84(1), 97-110. https://doi.org/10.1037/0022-3514.84.1.97

Delhaye, M., Beyers, W., Klimstra, T., Linkowski, P., \& Goossens, L. (2012). The Leuven Adolescent Perceived Parenting Scale (LAPPS): Reliability and validity with French-speaking adolescents in Belgium. Psychologica Belgica, 52(4). 289-305. https://doi.org/10.5334/pb-52-4-289

Diener, E., Wirtz, D., Tov, W., Kim-Prieto, C., Choi, D.W., Oishi, S., \& Biswas-Diener, R. (2010). New well-being measures: Short scales to assess flourishing and positive and negative feelings. Social Indicators Research, 97(2), 143-156. https://doi.org/10.1007/s11205-009-9493-y

Downie, M., Chua, S.N., Koestner, R. Barrios, M.-F., Rip, B., \& M'Birkou, S. (2007). The relations of parental autonomy support to cultural internalization and well-being of immigrants and sojourners. Cultural Diversity and Ethnic Minority Psychology,13, 241-249. https://doi.org/10.1037/1099-9809.13.3.241 
Fletcher, A.C., Walls, J.K., Cook, E.C., Madison, \& K.J., Bridges, T.H. (2008). Parenting style as a moderator of associations between maternal disciplinary strategies and child well-being. Journal of Family Issues, 29, 17241744. https://doi.org/10.1177/0192513X08322933

Fung, J. \& Lau, A.S. (2012). Tough love or hostile domination? Psychological control and relational induction in cultural context. Journal of Family Psychology, 26(6), 966-975. https://doi.org/10.1037/a0030457

Gençöz, T. (2000). Positive and Negative Affect Schedule: A study of validity and reliability. Türk Psikoloji Dergisi, 15(46), 19-28.

Gök, E., \& Kocayörük, E. (2019). Temel psikolojik ihtiyaçlar, aile aidiyeti ve ebeveyn algisı değişkenlerinin öznel iyi oluş üzerindeki etkisi. Aile Psikolojik Damıs̆manliğg Dergisi, 2(2), 21-51.

Grolnick, W. \& Rfatery-Helmer, J. (2013). Facilitating autonomy in the family: Supporting intrinsic motivation and self-regulation. In B. Sokol, F. Grouzet, \& U. Muller (Eds), Self-regulation and autonomy: Social and developmental dimensions of buman conduct (pp. 141-164. Cambridge University Press. https://doi.org/10.1017/CBO9781139152198.011

Güngör, D. (2008). The meaning of parental control in migrant, sending, and host communities: Adaptation or persistence? Applied Psychology: An International Review, 57, 397-416. https://doi.org/10.1111/j.1464$\underline{0597.2007 .00323 . \mathrm{x}}$

Helwig, C.C., To, S., Wang, Q., Liu, C., \& Yang, S. (2014). Judgments and reasoning about parental discipline involving induction and psychological control in China and Canada. Child Development, 85(3), 11501167. https://doi.org/10.1111/cdev.12183

Hofstede, G. (2001). Culture's consequences: Comparing values, behaviors, institutions, and organizations across nations, (2nd Ed.) Sage. Doi: 10.1016/S0005-7967(02)00184-5

Kağıtçıbaş1, Ç. (1996). Family and human development across cultures: A view from the other side. Lawrence Erlbaum.

Kındap, Y., Sayıl, M., \& Kumru, A. (2008). Anneden algilanan kontrolün niteliği ile ergenin psikososyal uyumu ve arkadaşlıkları Arasındaki İlişkiler: Benlik değerinin aracı rolü [The relationships among type of perceived maternal control, psychological adjustment, and friendship in adolescence: The moderating role of selfesteem]. Türk Psikoloji Dergisi, 23(61), 92-107.

Kins, E., Beyers, W., Soenens, B., \& Vansteenkiste, M. (2009). Patterns of home leaving and subjective well-being in emerging adulthood: The role of motivational processes and parental autonomy support. Developmental Psychology, 45(5), 1416-1429. https://doi.org/10.1037/a0015580.

Kocayörük, E. (2007). Lise Öğrencilerinin Yabancllaşmaları ile Anne Baba İlişkileri Arasındaki İlişkinin İncelenmesi. Eğitim Bilim Toplum, 5(17), 92-111.

Kocayörük, E. \& Sümer, Z. (2009). Baba katılım eğitiminin aile işlevlerine ve ergenlerin akran ilişkilerine etkisi. Eğitimde Kuram ve Uygulama Dergisi, 5 (1), 3-17.

Laird, R.D., Marrero, M.D., \& Sentse, M. (2010). Revisiting parental monitoring: Evidence that parental solicitation can be effective when needed most. Journal of Youth and Adolescence, 39, 1431-1441. doi: 10.1007/s10964-0099453-5.

Lan, X., Ma, C., \& Radin, R. (2019). Parental autonomy support and psychological well-being in Tibetan and Han emerging adults: A serial multiple mediation model, Frontier Psychology, 10, 621. https://doi.org/10.3389/fpsyg.2019.00621

Lau, S., \& Cheung, P.C. (1987). Relations between Chinese adolescents' perception of parental control and organization and their perception of parental warmth. Developmental Psychology, 23(5), 726729. https://doi.org/10.1037/0012-1649.23.5.726 
Markus, H.R., \& Kitayama, S. (1991). Culture and the self: Implications for cognition, emotion, and motivation. Psychological Review, 98(2), 224-253. https://doi.org/10.1037/0033-295X.98.2.224

Martín-Carbonell, M., Espejo, B., Checa, I., Fernández-Daza, M. (2021). Adaptation and measurement invariance by gender of the Flourishing Scale in a Colombian sample. International Journal of Environmental Research and Public Health, 18, 2664. https:// doi.org/ 10.3390/ijerph18052664

Ngai, S.S-Y. \& Cheung, C-K. (2009). The effects of parental care and parental control on the internal assets of adolescent children in Hong Kong, International Journal of Adolescence and Youth, 15(3), 235-255. https://doi.org/10.1080/02673843.2009.9748031

Oyserman, D., Coon, H.M., \& Kemmelmeier, M. (2002). Rethinking individualism and collectivism: Evaluations of theoretical assumptions and meta-analyses. Psychological Bulletin, 128, 3-72. https://doi.org/10.1037/0033$\underline{2909.128 .1 .3}$

Pomerantz, E.M., \& Wang, Q. (2009). The role of parental control in children's development in Western and East Asian countries. Current Directions in Psychological Science, 18(5), 285-289. https://doi.org/10.1111/j.14678721.2009.01653.x

Rudy, D., \& Grusec, J.E. (2006). Authoritarian parenting in individualist and collectivist groups: Associations with maternal emotion and cognition and children's self-esteem. Journal of Family Psychology, 20(1), 68-78. https://doi.org/10.1037/0893-3200.20.1.68

Rudy, D., \& Halgunseth, L.C. (2005). Psychological control, maternal emotion, and cognition, and child outcomes in individualist and collectivist groups. Journal of Emotional Abuse, 5(4), 237264. https://doi.org/10.1300/J135v05n04 04

Sevim, S.A. (2014). Leuven Algylanan Ana Babalık Ölçeği [Adaptaion of parent and adolescent versions of Leuven Adolescent Perceived Parenting Scale]. Düșinen Adam: Psikiyatri ve Nörolojik Bilimler Dergisi, 27(4), 291-300. doi: 10.5350/DAJPN2014270402

Soenens, B., Beyers, W., Vansteenkiste, M., Sierens, E., Luyckx, K., \& Goossens, L. (2004, July). The "gross anatomy" of parenting styles in adolescence: Three or four dimensions? Paper presented at the 18th biennial meeting of the International Society for the Study of Behavioural Development (ISSBD) Ghent Belgium.

Soenens, B., Vansteenkiste, M., Lens, W., Luyckx, K., Goossens, L., Beyers, W., \& Ryan, R.M. (2007). Conceptualizing parental autonomy support: Adolescent perceptions of promotion of independence versus promotion of volitional functioning. Developmental Psychology, 43(3), 633- 646. https://doi.org/10.1037/0012$\underline{1649.43 .3 .633}$

Suchman, N.E., Rounsavilla, B., DeCosta, C., \& Luthar, S. (2007). Parental control, parental warmth, and psychosocial adjustment in a sample of substance-abusing mothers and their school-aged and adolescent children. Journal of Substance Abuse Treatment, 32(1), 1-10. doi: 10.1016/j.jsat.2006.07.002.

Sunar, D. (2002). Change and continuity in the Turkish middle-class family. Autonomy and dependence in family: Turkey and Sweden in critical perspective, In R.Liljestrom \& E. Özdalga (eds.), Autonomy and dependence in the family (pp. 217-238). Swedish Research Institute.

Tamis-LeMonda, C.S., Way, N., Hughes, D., Yoshikawa, H., Kalman, R.K., \& Niwa, E.Y. (2008). Parents' goals for children: The dynamic coexistence of individualism and collectivism in cultures and individuals. Social Development, 17(1), 183-209. https://doi.org/10.1111/j.1467-9507.2007.00419.x

Tepe, E.E. \& Demir A. S. (2019). Babaların çocuk bakımına katılımında kendi annelerinin etkisi üzerine bir çalışma: Sakarya ili örneği. Uluslararast Folklor Akademi Dergisi, 2(1), 121 -140.

To, S., Helwig, C.C., \& Yang, S. (2017). Predictors of children's rights attitudes and psychological well-being among rural and urban Mainland Chinese adolescents. Social Development, 26(1), 185-203. https://doi.org/10.1111/sode.12195 
Van der Giessen, D., Branje, S., \& Meeus, W. (2014). Perceived autonomy support from parents and best friends: Longitudinal associations with adolescents' depressive symptoms. Social Development, 23(3), 537-555. https://doi.org/10.1111/sode.12061

Villieux, A., Sovet, L., Jung, S.C., \& Guilbert, L. (2016). Psychological flourishing: Validation of the French version of the flourishing scale and exploration of its relationships with personality traits. Personality and Individual Differences, 88, 1-5. https://doi.org/10.1016/i.paid.2015.08.027

Wang, Q., Pomerantz, E.M., \& Chen, H. (2007). The role of parents' control in early adolescents' psychological functioning: A longitudinal investigation in the United States and China. Child Development, 78(5), 15921610. https://doi.org/10.1111/j.1467-8624.2007.01085.x

Wang, C. Xia, Y., Li, W., Wilson, S.M., Bush, K. \& Peterson, G. (2016). Parenting behaviors, adolescent depressive symptoms, and problem behavior: The role of self-esteem and school adjustment difficulties among Chinese adolescents. Journal of Family Issues, 37(4), 520-542. https://doi.org/10.1177/0192513X14542433

Watson, D., Clark, L. A., \& Tellegen, A. (1988). Development and validation of brief measures of positive and negative affect: the PANAS scales. Journal of Personality and Social Psychology, 54(6), 1063-1070. doi: 10.1037//0022-3514.54.6.1063.

Wu, P., Robinson, C.C., Yang, C., Hart, C.H., Olsen, S.F., Porter, C.L., ...\& Wu, X. (2002). Similarities and differences in mothers' parenting of preschoolers in China and the United States. International Journal of Behavioral Development, 26, 481 -491. https://doi.org/10.1080/01650250143000436

Zarra-Nezhad M., Aunola K., Kiuru N., Mullola S., \& Moazami-Goodarzi, A. (2015). Parenting styles and children's emotional development during the first grade: The moderating role of child temperament. Journal of Psychology \& Psychotherapy, 5, 206. doi: 10.4172/2161-0487.1000206 


\section{About Authors}

Ercan Kocayörük is a professor of Psychological Counseling and Guidance at Çanakkale Onsekiz Mart University, Faculty of Education. He has studied about counseling applications and practices in school over 25 years. He is a researcher in the field of relationship between parents and children and the role of parents on healthy adolescent development.

Tugay Tutkun works as an Associate Professor at Çanakkale Onsekiz Mart University, Faculty of Education, Department of Educational Sciences, Department of Curriculum and Instruction. He teaches courses such as Introduction to Educational Sciences, Teaching Principles and Methods, Measurement and Evaluation at the undergraduate level; Curriculum Development in Education, Curriculum and Technology Integration and Statistics at the graduate level. He has several proceedings published in scientific meetings and articles published in scientific journals in his study topics; media literacy, active citizenship, social equity and e-learning

Hamide Gözü is an Assistant Professor at the Çanakkale Onsekiz Mart University, Faculty of Education, Department of Educational Sciences, Department of Counselling and Psychology. Dr. Gözü has worked on parent-child, sibling, and peer relationships. She has many published articles and notifications.

Ömer Faruk Şimşek is an professor of psychology at Istanbul Rumeli University, Department of Psychology. His main areas of research and interest are subjective well-being and its relation to narrative processes, language use and mental health, personal sense of uniqueness, and self-consciousness. He is also interested in usingadvanced statistical analyses such as multitrait multimethod analyses and growth curve modeling.

Emin Altintas is an Associate Professor of Psychology at Université de Lille (France) and had PhD in Psychology at the same university. He has worked on well-being, time perspective, motivation and aging at international level. Emin Altintas is also Clinical Psychologist in Centre Hospitalier de Tourcoing (France).

\section{Author Contributions}

This study was conducted by all the authors working together and cooperatively. All of the authors substantially contributed to this work in each step of the study.

\section{Conflict of Interest}

It has been reported by the authors that there is no conflict of interest.

\section{Funding}

This study is supported by The Scientific and Technological Research Council of Turkey (TUBITAKGrant:115K417).

\section{Ethical Statement}

This research was completed in line with the Helsinki Declaration. In line with this, the study was investigated and permitted by Canakkale Onsekiz Mart Unıversity Scientific Research and Ethical Review 
Board. Additionally, data tools in the study were only distributed to volunteer participants. All participants provided informed consent. Additionally, participants were informed that they could withdraw from the study at any time during data collection.

Ethics Committee Name: Canakkale Onsekiz Mart Unıversity Ethics Committee Approval Date: 29/08/2014.

Approval Document Number: ÇOMÜ/2104/19 